\title{
Spatializing Law in a Comparative Perspective of Legal History
}

Spacialiser le droit dans une perspective d'histoire juridique comparée

Jean-Louis Halpérin

\section{OpenEdition}

1 Journals

Electronic version

URL: http://journals.openedition.org/extremeorient/644

DOI: 10.4000/extremeorient.644

ISBN: 978-2-84292-558-1

ISSN: 2108-7105

Publisher

Presses universitaires de Vincennes

Printed version

Date of publication: 21 November 2016

Number of pages: $207-218$

ISBN: 978-2-84292-556-7

ISSN: 0754-5010

\section{Electronic reference}

Jean-Louis Halpérin, « Spatializing Law in a Comparative Perspective of Legal History », Extrême-Orient Extrême-Occident [Online], 40 | 2016, Online since 21 November 2018, connection on 20 April 2019 URL : http://journals.openedition.org/extremeorient/644 ; DOI : 10.4000/extremeorient.644 


\title{
Spatializing Law in a Comparative Perspective of Legal History
}

\author{
Jean-Louis Halpérin
}

How to justify, at the end of this volume, a comparative point of view from an outsider who is not a specialist of Chinese legal history? A first argument can be found in the recent developments of comparative legal history. A European Society for Comparative Legal History has been founded in 2009 and has gathered many legal historians in Europe who are trying to work together about journals, handbooks or casebooks in a transnational perspective. ${ }^{1}$ The Max-Planck Institutfür europäische Rechtsgeschichte in Frankfurt am Main has devoted a symposium and an issue of the review Rechtsgeschichte (2014) to the transnational perspectives of legal history today, including in territories outside Europe, especially in Asia. ${ }^{2}$ In this Institute, Thomas Duve has particularly focused collective research works about the colonial or quasi-colonial situations that have given birth to transplanted or hybrid rules. ${ }^{3}$ Legal Historians are more and more sensitive to the narrowly-tailored tradition of their discipline based on national frames and, for a long time, on nationalistic biases. They are more and more prone to study legal circulations among the national systems, to take account of the relationships between the centre of legal traditions and the periphery and to considerer colonial law as an important component of legal developments since the 16th century. ${ }^{4}$ It can be said that forty years after the pioneering and discussed works of Alan Watson concerning legal transplants, ${ }^{5}$ legal history has known a hermeneutical

1. Three volumes of the review Comparative Legal History have been edited by the ESCLH since 2013.

2. Rechtsgeschichte. Legal History Rg, 22, 2014 with, for example, a paper of Li 2014 and a paper of Zhang 2014.

3. Duve 2014.

4. Halpérin et al. 2014: 183-203.

5. Watson 1974 and 1977. 
turn towards a study of interactions and relationships between legal systems. Legal history is no more conceived as the study of the development of national systems that would be linked with national spirits and cultures. On the contrary, there is a reaction against stereotypes and unhistorical "clichés" concerning the traditional features or characters attributed to legal orders or families. The influence of legal pluralism, even if it is less or more accepted by legal historians, is not without impact on these new perspectives of combining legal history and comparative law.

A second argument, that is more personal than the precedent, concerns the methodological reflection in legal theory as it can be applied to historical issues. Although all legal historians do not share this opinion, it seems to me that legal history, as history in general, is a viewpoint moving back from the present to the past. Our questions and problems are conceived from nowadays issues and expressed with our contemporary vocabulary. As many legal historians have received the education of a jurist, they use the words and the concepts of their national system and language, and more generally of modern law. Of course, they know that the past legal rules they are studying were often foreign to these modern schemes of thinking. But they cannot think "as a lawyer of the past" and resurrect the way of thinking of persons who died several centuries ago. As a consequence, every study in legal history involves a comparison between the past and the present, between the issues we are studying in "ancient law" and the questions we are asking in our modern vocabulary linked with our knowledge of our legal system. As Joseph Raz has noticed, we are using our concept of law, dependent on the observer, to study foreign or past systems of law. ${ }^{6}$

As a positivist, I think that it is necessary for studying law (and specially the legal rules of the past) to get a minimal definition of law, which means a distinction between legal norms and other kinds of norms. I follow the method used by Herbert Hart or by Joseph Raz to find these unique features or characters of law not in the content of norms (what leads to natural law conceptions, identifying law with ideals of justice), but in formalist criteria that make law differ from other normative systems. It means that law, as a technology, has been ignored by some societies and has been invented in historical configurations that can be identified. The attempt made by Hart to identify these criteria, as three secondary rules (of recognition, change, and adjudication) associated with primary rules to constitute a legal system, ${ }^{7}$ seems to be the more convincing and more operating method in legal history.

6. Raz 2009: 17-46.

7. Hart 1961: 93-95. 
It provides the advantage not to be dependent of the traditional, sometimes questionable, translations of foreign and past words into our legal vocabulary (for example, considering that the Hindu dharmasastras are equivalent to law). According to Hart, a legal system is not only a set of rules of conduct (that can be found in other normative systems), but these "primary rules" must be completed by three adjective or procedural rules (or group of rules, it is not necessary that every secondary rule could be resumed in one sentence or would be expressed by the contemporaries). The rule of recognition allows to acknowledge what is an authoritative rule imposed by the rulers to the ruled. The rule of change determines who can amend the rules and which process should be followed for that. The rule of adjudication gives the power to judges for deciding litigation about the primary rules. Hart has considered that the writing down of primary rules (generally with an express order to obey them and an information given to judges) is a first step in the establishment of a rule of recognition.

If one uses Hart's scheme, it is possible to make a difference, in Antiquity, between the legal system of the Romans-with the presence of the three secondary rules from the age of the Law of the Twelve Tables (middle of the fifth century B.C.) - and normative regulations which have been assimilated to law through tradition but are not likely to be recognized as law because they lack the three secondary rules. In the Western world, one can consider not only that Romans have invented law, but that they were not preceded by Egyptians, Greeks or Mesopotamians whose regulative systems cannot be identified as law before the fifth century B.C., as Aldo Schiavone has recently shown ${ }^{8}$ It can be reproached to Hart's scheme to be ethno-centred and available only for Western (or Westernized) systems of law. The Chinese experience is the best example of a useful comparison based on these formal criteria. Among specialists, there is no doubt today that there was, since the Antiquity, a rule of recognition (about what constituted the $f a$ ), a rule of change (thanks to the succession of different statutes in the same kingdom, then in the unified empire) and a rule of adjudication (through a system of public courts) associated with the rules of conduct that were sanctioned by penalties. If one adds that Chinese law, like Roman law, was not strongly linked with a religious system supposing the divine origin of laws, the Chinese legal systems appears more comparable to the Roman one than to the religious "normativities" of the so-called Jewish or Islamic laws.

The archaeological excavations since the years 1970s, notably the discovery of many bamboo tables in the tombs dealing with penal statutes or cases, leads

8. Schiavone 2005: 5 . 
to the identification of the age of the law's invention in China between the sixth and the third century B.C., firstly inside the Warring States, then in the Qin Empire. ${ }^{9}$ The fact that this period corresponds to the chronology of the invention of law in Rome, and probably in the Jewish world with the writing down of the Torah attributed to Ezra the scribe, is a pure coincidence. Hart's criteria allow to consider that the legal technology has been invented separately (and used in different ways) in various places of the world. Such a method has also led to reject Max Weber's conceptions about an imperfect development of law in ancient China that would be linked with the "absence of lawyers". ${ }^{10}$ On the contrary, it can be said that Chinese have invented the law in the Far East and, from the Qin dynasty onwards, constructed a strong legal system based on statutory laws and on codes. Speaking of a "Chinese State" from the Antiquity is not an abuse of language but a justified recognition of the construction of a Chinese legal order that can be assimilated with a State (and with a centralized one) according to Kelsen's theories. ${ }^{11}$

For all these reasons, there are some questions linked with the invention of law and the construction of States (then their transformation in "modern" States) that are common to legal historians of the Western world and of China. For example, the relationship between "military" and "civil" law is likely to concern the historians of Roman law as well as those of Chinese law. ${ }^{12}$ In this volume, the various contributions are focused on law during the Ming and Qing dynasties and the subject for comparative legal history is not the one of the invention of the law. The main problem is the spatial application of legal rules in relationship with the conquests of new territories during the 17 th and the 18 th century.

What is well known by the specialists of Chinese history, the transition from the Ming Empire of the eighteen provinces to the conquests of the emperor Qianlong (1735-1796) in the West of China (pacification of Xinjiang, campaigns in Burma, Tibet and Vietnam), appears to outsiders as something comparable with the development of new colonial empires in the 18th and 19th centuries (the British empire in India, the Russian empire in Turkestan). If a Western point of view has linked colonization with overseas territories and with the history of "the age of great discoveries," it seems possible to make new taxonomies about the imperial sovereignty. What is common (or at least comparable) between the Chinese, the British and the Russian empires during

9. Liu 1998; Chang 2007: 335.

10. Bourgon 2007: 241-58.

11. Gernet 2006: vol. 1.

12. Yates 2009: 23-41. 
the 18th and the 19th century (and one part of the 20th century) is the extension of a legal system conceived first as a domestic (or "municipal" as Blackstone said for the common law in his 1765-1769 Commentaries) to heterogeneous peoples who had their own customs (as regulative rules for their societies) and in some cases their own legal norms. As the British colonizers have "recognized" the status of personal laws for Muslims and Hindus (what was easier for the first category, endowed with a structured normativity, than for the second group, deprived from a true "Hindu law"), the Chinese conquerors had to resolve the questions of the law applicable to Mongol or Uyghur tribes, to Hui or Miao people. The Chinese were confronted with the tensions between a codified Han law - the one of the 1646 Qing Code, then of the 1740 Code of the Great Qing (with the integration of $l i$ as true statutes put on an equal footing with $l i i)$ - Muslim law (as applied by some of the subjected peoples) and personal customs. Jérôme Bourgon has shown how it is difficult to speak about "custom" and "customary law" in a centralized legal system as the Chinese one, which was based on statutes applied by imperial judges. In such a system there was no specific room for "local" customary law linked with a territory or a determined group of people. To avoid any confusion between law and facts (what is the goal of legal theory for positivists and do not prevent from recognizing a gap between "law in books" and "law in action"), it is useful, let alone necessary, to prohibit the word "custom" in order to qualify legal practices as the ones resulting from the case law. ${ }^{13}$ Such a methodological cautiousness is not inconsistent with the recognition of local or customary laws in the Chinese colonized "Far West". The problems linked with colonial empires are those of the obstacles to a quick and complete integration of heterogeneous peoples in a unified legal system. In all the empires, these problems were resolved in admitting (according to different patterns) a "layered" sovereignty with a spatialization of norms including some kinds of "personal" status. ${ }^{14}$

For these reasons, all the papers gathered in this volume can suggest some comparisons with colonial situations concerning the European empires in the 18th and 19th centuries. Some of these empires have known a rather strong system of statutory laws, others were based on a complex of statutory and case law. One thinks about France for the first ideal-type: even before the Napoleonic codification, which was applied in overseas territories only for colonizers, the French monarchy knew large statutes, as the 1667 and 1670

13. Bourgon 2003: 243-82.

14. Benton 2009. 
ordinances of Louis the fourteenth concerning civil and penal procedures. ${ }^{15}$ Great Britain is of course the kingdom of a common law based on case law, but with a complex web of penal statutes developed in the 18th century, at the same time than the recognition of Muslim and Hindu personal laws in India. If the legal frame, as the administrative one, is different in China, one can understand that the concepts of "local laws", "personal laws" or adaptations of law linked with a very large space are elements of a fruitful comparison between the Chinese and the European (and colonial) situations.

Let us take, in a first stage, the problems that were caused by the great distance between the centre and the periphery of the empire. The difficulties, described by Xie Xin-zhe, to realise autopsies according to the legal rules (what means in a short delay), in the most remote parts of judges districts can be compared with other configurations in legal history. How Roman governors could be informed and moved in action for cases happening at the limits of their province? How French judges of the Parliament of Toulouse could lead criminal investigations in some parts of the Pyrenean mountains? How British administrators (and colonial judges) could control legal situations in the furthest parts of their district? ${ }^{16}$

The question of penal banishment in the Chinese empire, as examined in Frederic Constant's paper, is also significant of the many attempts to transform the medieval forms of banishment outside a rather small territory (which were not very efficient in a modern State) into "modern" systems of transportation in the galleys (in France during the 17th and the 18th centuries corresponding to the period of the first Qing emperors), then in penal colonies (specially for the British in America, then in Australia). Of course, the situation is not the same for continental empires, like the Chinese and the Russian ones (with Siberia as a huge space for penal banishment) and for maritime empires. But, in both cases, spatialization of the law of punishment does not mean a diversity of local laws (it is the same law that is applied inside the whole empire) but the determination of zones where peoples are concentrated (and sometimes used for military goals) according to a penal (and legal) status.

Another issues concern the establishment of local or personal laws in the penal field. Eric Schluessel shows how governors could be empowered to decide local rulings, notably for making immediate executions (executions on the spot) of death penalties, contrary to the fundamental rule of Chinese law requiring the confirmation of death penalties by the emperor. Here again,

15. It is noteworthy that the Qing Code of the same period was a true penal code, which lacked in France.

16. Some of these questions are dealt with in the memoirs of John Beames 1984. 
the substantial rule is the same for the whole empire (the same offences are punished with the death penalty), but the deterrent goal (also present in the penal exile) of the penalty is linked (as in Beccaria's treatise) with a swift execution at the place of the crime. These local rules can be interpreted as well as forms of "flexibility" in a centralized system and as kinds of "martial laws" used in conquered territories.

A third stage can be analysed as specific local and penal rules adapted to non-Han peoples. The "law of the Miaos", studied by Zhang Ning, is a part of the 1740 Code with about twenty specific sub-statutes. These statutes are focused on special crimes, notably the traffic of human beings linked with the revenge (or vendetta) and compensation traditions among the Miaos. One can observe that the Chinese statutory law targeted an ethnic group for a "supraprovincial crime" (comparable to interstate criminality in federal states). It is not properly a personal law recognizing Miaos' practices as a customary law (on the contrary, the Miaos were punished to act according their social habits), but a local law that let the Chinese State maintain and control forms of slavery. In the same time, one can ask if these specific statutes, submitting the more serious offences to imperial laws (and even to the emperor's approbation for sentences involving the death penalty), were not an accommodation with the "civil" rules that Chinese judges could deduce from Miao customs in cases between two Miao litigants. Here a comparison would be possible with the decline of personal penal laws in Western colonial empires (as well in British India as in French Algeria) and the recognition of a personal "civil" law in family matters.

Whang Zhiqiang speaks deliberately of "regional sub-statutes" about the 217 penal rules that are assigned to a particular territory. Some of these regional statutes concerned the capital of the empire and reinforced the special status of the centre of the empire, as the regulations applied to London or Paris were not inconsistent with unified legal system. But many others concerned the periphery of the empire and were initiated by specific demands from the governors of remote provinces. Here a comparison can be made with the rescripts of the Roman governors that were addressed to the emperor's chancellery and were answered by imperial jurists attempting in some situations to accommodate Roman law with specific habits of the indigenous inhabitants. ${ }^{17}$ Because many of these statutes applicable to indigenous populations at the periphery of the empire were more severe than the ordinary legislation, one can also think about the so-called Code de l'indigénat-in fact not a comprehensive code, but a series of special penal laws applied from the years 1880s to indigenous in

17. Coriat 1997. 
the different French colonies, notably for authorizing administrative detention and forced work in cases of disobedience ${ }^{18}$. But this last comparison is limited: the indigenat regime was part of a kind of administrative law outside the penal codification, whereas the Chinese have integrated these specific laws in their unique codification. Furthermore, the persons affected by these regional rules could be recognized as an ethnic group (that is not exactly the same as colonized subjects) and there are some contacts with the kind of "foreign laws" recognized by the Chinese rules, as the Mongol Code, the regulations for Turkestan or the so-called "Fan code".

This Fan Code is the subject of Max Oidtmann's paper through the study of a litigation dealing with domains of lamas and monasteries in Amdo (province of Gansu). In this territory the Chinese rulers have subjected populations, which have known the 1640 Mongol-Oirat code and which were later separated from their former Mongol rulers. Having the conviction that Fan people were too barbarous to have their own legal system, the Chinese colonizers considered that they could extract a "Fan law" from the Mongol statutes. Chinese rulers acted in consultations with Tibetan and Mongol elites and promulgated, as a kind of privilege, sixty-eight statutes translated in Tibetan language. Named as the Fan's "own customs", these statutes were rather a set of imperial laws that were applicable locally to all the inhabitants of a region, the Mongols as well as the Tibetans. The process consisting in recognizing as laws some indigenous norms and in translating into a vernacular language "foreign" norms written in another language can be compared with the British translations of Persian or Hindu texts that were in a second stage imposed to Muslims or Hindus in India. ${ }^{19}$ But the Fan Code is more a regional law than a personal status and it seems to have been accepted (and even claimed) by the local communities of Tibetans. However, these local laws remained imperial statutes and were not autonomous regulations decided by a regional power. The comparison between Whang Zhiqiang's study of special (penal) laws, integrated in the Code, and this Fan Code admitting compensations instead of penalties is the proof of a variety of policies from the Chinese rulers to adapt their legal system to different colonial situations.

The same remark can be made about military law in imperial China as studied by John Gregory. First, there is a great continuity between Chinese dynasties in dealing with military law: if there is a clear policy to have special statutes and militarized (what means more accelerated) adjudication for

18. Merle 2006: 97-115.

19. Bhattacharyya-Panda 2008; for a general problematic about these processes of inventing customary laws, Halpérin 2012: 405-23. 
military offences, this military law was part of the code and some military crimes were subjected to the ordinary retrial-review process. Military law was not associated with an arbitrary power of Chinese warriors, but used as a "regular" law. Second, this military law was applied in the same time during the conquest of new territories and for the administration of colonized provinces by governors of the frontiers. As the Qing were Manchu conquerors of China (fighting against Southern Ming in the 17th century), then colonizers of huge territories in the West (during the 18th century), the areas subjected to military laws were expanded (and not limited to extreme frontiers) during the 17th and 18th centuries. Military law cannot be qualified as an exception or something to get round the legal rules. It is a part of nuanced policies to subject territories to the Chinese legal system.

For all these reasons, the different ways for spatializing the law in the modern history of imperial China can be analysed as structural reforms of an old and sophisticated legal system rather than exceptions to the rule of law. China has known, as other countries especially in Europe between the 17th and the 19th centuries, situations of political urgency and of legal emergency. The case of Lin Zexu's action against the British opium trade is well known, but Lin Zexu was dismissed and his policy was not approved by central authorities. In the longue durée, one can be struck by the will of Chinese rulers to "regularize" all the practises linked with a special treatment of legal rules according to the territory or the population. If these attempts to adapt the Chinese legal system cannot be reduced to a single policy, they can be described as elements of a voluntary plan to make the Chinese legal system consistent with a new territorial empire, including more and more no-Han peoples.

With such a perspective, the Chinese legal history could be studied, in comparison with Western polities and empires, as an example of the legal transformation of the State. As I have said, one can consider that there is a legal order and a State apparatus in China since the foundations of the empire, what means a long time before the apparition of "States" in the Western world. If the invention of law in China and in Rome were not very far in time one from another, the transformation of the republican city of Rome in a bureaucratic empire did not happen before the second and third century A.D., whereas the Chinese empire was organized with a powerful apparatus from the third century B.C. Of course, the two spaces, the Western and the Chinese ones, have known long periods of weakness, and even of disappearance, of the State legal and political structures. If we consider the situation at the beginning of the Qing dynasty, there is again no doubt about the existence of a Chinese State, notably with the centralization of justice and the review process of death penalties 
before the emperor. The question is to determine if the Chinese empire has known the mutation towards what we call in Occident a "modern State".

For a long time, it has been considered that the Qing Empire was relatively weak in its structures in order to explain its defeats towards foreign powers that begun with the Opium War. There is today a clear re-evaluation of a "peak of power" of the Qing Empire during the 18th century ${ }^{20}$. If one combines this analysis with Lauren Benton's theories concerning the specificities of empires towards ordinary States (that is to say States without great territorial extensions during the Modern Times), it seems possible to develop an hypothesis about the features of many modern States in the Western world as in China. In a legal perspective, traditional States were based on a control of the judiciary by the central institutions and a hierarchy of courts: it was the case for medieval States in Europe like England or France, for Muslim States at the epoch of the Abbasid Caliphate, for the Church at the climax of pontifical theocracy and for the Chinese Empire during the Ming Dynasty. For all the States which conquered and controlled new territories overseas (the Spanish, Portuguese, Dutch, English and French States in Europe) or in a "far" east (Prussia, Russia), south (Ottoman Empire) or west (China), there were new legal needs to develop a more complex and layered structure. If all these empires could be more or less centralized, the increasing problems of legal spatialization in vast and various areas led to the idea of developing personal laws and of letting a margin of autonomy to governors at the periphery. In many cases the colonizers were confronted with heterogeneous peoples endowed with their own customs, let alone with a different legal system as the Muslim one (and Chinese rulers encountered the Islamic law as well as European colonizers). The recognition of "personal status" and the transformation of indigenous customs into customary laws (integrated in the whole system) were "economic" solutions to control new subjects without renouncing to impose the law of the conquerors.

All the studies in this volume are focusing about these different means to develop a modern State in China during the Qing dynasty. The use of substatutes, special laws, military laws or customary rules recognized by the judges was a path towards what we call a "hierarchy of norms". In the same code, it was clear that the purely Chinese laws (as a kind of "public policy") were superior to all the local rules, even if these special rules could derogate to the general ones.

As Ulrich Theobald has shown in his paper, the common feature between administrative regulations and judicial precedents is the creation of local regulations that were embedded in a comprehensive legal order. In the absence

20. Waley-Cohen 2004: 193-206. 
of any movement of legal protestation - as the one of American insurgents who did no more support to be subjected to "subordinated constitutions" in the British Empire - one must wait the end of the Qing Dynasty in China to imagine the writing down of a central constitution and of several provincial constitutions. Contrary to the pluralistic conceptions, this complexification of the legal order was not the result of "spontaneous" customary resisting to the centralisation, but a consequence of State policies letting a small room for customary or local rules. If one adds that these legal constructions depended on various practices and precedents in the different parts of the empire, it is understandable that the Chinese lawyers did not get a word for "custom" before the contacts with Western and Japanese jurists ${ }^{21}$. The comparison between legal history in the Western world and in Asia is the proof that we can use and discuss an analytical concept of law and confront it with a great array of empirical data without being prisoners of Europe-centred prejudices.

\section{BIBLIOGRAPHY}

BhATTACHARYYA-PANDA, Nandini (2008). Appropriation and Invention of Tradition. The East India Company and Hindu Law in Early Colonial Bengal. New Delhi: Oxford University Press.

BEAMES, John (1984). Memoirs of a Bengal Civilian. London: Eland.

BENTON, Lauren (2009). A Search for Sovereignty. Sovereignty, Law and Geography in European Empires. Cambridge: Cambridge University Press.

BouRGON, Jérôme (2007). "Aspects of Chinese Legal Culture: The Articulation of Written Law, State and Society: a review (part one)." International Journal of Asian Studies, 4: 241-58.

BOURGON, Jérôme (2003). "Coutumes, pratiques et droit en Chine. Quelques remarques

sur des termes couramment employés dans des ouvrages récents." Études chinoises, 22: 243-82.

BouRGON, Jérôme (1999). "La coutume et le droit en Chine à la fin de l'Empire." Annales. Histoire, Sciences sociales, 54/5: 1073-1107.

Chang, Chunshu (2007). The Rise of the Chinese Empire, vol. I, Nation, State and Imperialism in Early China, ca. 1600 B.C.-A.D. 8. Ann Arbor: The University of Michigan Press.

CORIAT, Jean-Pierre (1997). Le Prince législateur. La technique législative des Sévères et les modes de création du droit impérial à la fin du Principat. Paris: École française de Rome.

21. Bourgon 1999: 1073-1107. 
Duve, Thomas (ed.) (2014). Entanglements in Legal History: Conceptual Approaches. Frankfurt am Main: Max Planck Institute for European Legal History.

GERNET, Jacques (2006). Le Monde chinois. Paris: Pocket, « Agora ».

Halpérin, Jean-Louis (2012). "La détermination du champ juridique à la lumière de travaux récents d'histoire du droit." Droit et Société, 81: 405-423.

HALPÉRIN, Jean-Louis et al. (2014). "Histoire comparée du droit." In L'Histoire du droit en France. Nouvelles tendances, nouveaux territoires, edited by Jacques KRYNEN, Bernard d'AlTEROCHE. Paris, Garnier : 183-203.

HART, Herbert Lionel Adolphus (1961). The Concept of Law, Oxford, Oxford University Press.

LI, Xiuqing (2014). "The Chinese Repository and Chinese Criminal Law in the Minds of Westerners of the 19th Century." Rechtsgeschichte-Legal History Rg, 22: 15874.

LIU, Yongping (1998). Origins of Chinese Law. Penal and Administrative Law in its Early Development. Hong Kong/Oxford/New York: Oxford University Press.

MERLE, Isabelle (2006). "L'État français, le droit et la violence coloniale.” In Figuration des Staates in Deutschland und Frankreich 1870-1945, edited by Alain and Dieter GosEWINKEL. München, R. Oldenbourg : 97-115.

RAZ, Joseph (2009). Between Authority and Interpretation: On the Theory of Law and Practical Reason. Oxford: Oxford University Press.

Schiavone, Aldo (2005). Jus. L'Invenzione del diritto in Occidente, Roma/Bari: Laterza.

WALEY-COHEN, Joanna (2004). “The New Qing History”. Radical History Review, 88: 193-206.

Watson, Alan (1974). Legal Transplants. An approach to Comparative Law. Edinburgh: Scottish Academic Press.

Watson, Alan (1977). Society and Legal Change. Philadelphia: Temple University Press.

YATES, Robert (2009). "Law and the Military in early China." In Military Culture in Imperial China, edited by Nicola di Cosmo. Cambridge (Mass.), Harvard University Press : 23-41.

ZHANG, Zhongqiu (2014). "China's Selection of Foreign Laws for Succession in the Late Qing Dynasty.” In Rechtsgeschichte-Legal History Rg, 22: 176-90. 